- 研究报告・

\title{
青藏高原高寒草甸物种多样性的海拔梯度 分布格局及对地上生物量的影响
}

\author{
刘哲 ${ }^{1,2}$ 李 奇 ${ }^{1}$ 陈懂懂 ${ }^{1}$ 翟文婷 1,2 赵 亮 $^{1^{*}}$ 徐世晓 ${ }^{1}$ 赵新全 ${ }^{1,3^{*}}$ \\ 1 (中国科学院西北高原生物研究所, 西宁 810008) \\ 2 (中国科学院大学, 北京 100049) \\ 3 (中国科学院成都生物研究所, 成都 610041)
}

\begin{abstract}
摘要: 植物物种多样性在海拔梯度上的变化规律以及物种多样性与生产力的关系是生态学研究的热点, 至今还没 有得出一般性规律。本文以青海省海南藏族自治州贵德县的拉脊山( $36^{\circ} 21^{\prime} \mathrm{N}, 101^{\circ} 27^{\prime} \mathrm{E}$, 海拔3,389-3,876 m) 和果 洛藏族自治州的玛沈县军牧场山体 $\left(34^{\circ} 22^{\prime} \mathrm{N}, 100^{\circ} 30^{\prime} \mathrm{E}\right.$, 海拔4,121-4,268 m) 为研究对象, 对植物高度、盖度、地上 生物量和物种多样性随海拔高度的变化进行调查和统计分析, 以探讨青藏高原高寒草甸的物种多样性和地上生物 量在海拔梯度上的变化规律及两者的关系。结果表明: (1)两条山体样带上地上生物量与物种多样性随海拔的变化 规律一致: 随着海拔的升高, 地上生物量线性降低; Shannon-Wiener指数、Simpson指数和物种丰富度都呈单峰曲 线, 在中间海拔最大, 而Pielou指数随海拔的升高线性增加。结合目前针对青藏高原高寒草甸的研究数据, 发现物 种丰富度随海拔高度的变化均呈单峰曲线, 说明随着海拔的升高物种多样性先升高后降低可能是青藏高原物种多 样性分布的普遍规律。(2)地上生物量与物种多样性的关系在两条山体样带上表现一致：地上生物量随ShannonWiener指数、Simpson指数和Pielou指数的升高而线性降低, 但与物种丰富度不相关。综合两条山体样带所有样方 数据, 发现地上生物量与Shannon-Wiener指数、Simpson指数不相关, 而随物种丰富度的升高线性增加。结合目前 在青藏高原的相关研究数据, 发现地上生物量与物种丰富度呈S型曲线(logistic model)。
\end{abstract}

关键词: 物种多样性, 物种丰富度, 地上生物量, 生产力, 海拔, 多样性指数

\section{Patterns of plant species diversity along an altitudinal gradient and its effect on above-ground biomass in alpine meadows in Qinghai-Tibet Pla- teau}

\author{
Zhe $\mathrm{Liu}^{1,2}$, Qi Li ${ }^{1}$, Dongdong Chen ${ }^{1}$, Wenting Zhai ${ }^{1,2}$, Liang Zhao ${ }^{1 *}$, Shixiao $\mathrm{Xu}^{1}$, Xinquan Zhao ${ }^{1,3^{*}}$ \\ 1 Northwest Institute of Plateau Biology, Chinese Academy of Sciences, Xining 810008 \\ 2 University of Chinese Academy of Sciences, Beijing 100049 \\ 3 Chendu Institute of Biology, Chinese Academy of Sciences, Chengdu 610041
}

\begin{abstract}
Changes in plant species diversity along an altitudinal gradient and the relationship between biodiversity and productivity are important issues in ecology, which have not been addressed fully. To clarify the patterns of species diversity and above-ground biomass along an altitudinal gradient in alpine meadows, two representative mountains in Qinghai-Tibet Plateau were chosen as study subjects: Laji Mountain $\left(36^{\circ} 21^{\prime} \mathrm{N}\right.$, $101^{\circ} 27^{\prime}$ E) in Guide County, Hainan Tibetan Autonomous Prefecture and Junmuchang Mountain (34 $22^{\prime} \mathrm{N}$, $100^{\circ} 30^{\prime}$ E) in Maqin County, Golog Tibetan Autonomous Prefecture. Plant height, coverage, above-ground biomass, and species diversity with altitude change were investigated. We found that the patterns of above-ground biomass and species diversity along an altitudinal gradient in the two mountain transects are consistent. With an increase in altitude, the above-ground biomass decreased linearly; Shannon-Wiener in-
\end{abstract}

收稿日期: 2015-02-25; 接受日期: 2015-06-25

基金项目: 青海省科技项目(2013-Z-941Q)、中国科学院战略性先导科技专项(XDA05070200)、国家科技支撑计划(2014BAC05B04)、中国科学院西北 高原生物研究所知识创新工程领域前沿项目(2011)

* 共同通讯作者 Co-authors for correspondence. E-mail: lzhao@nwipb.cas.cn; xqzhao@nwipb.cas.cn 
dex, Simpson index and species richness present hump-shaped distributions, with the maximum value found in the middle altitudinal gradient, while the Pielou index increased regularly in a straight line with an increase in altitude. Combined with the present data for the alpine meadows in the Qinghai-Tibet Plateau, we found that species richness shows a hump-shaped curve with the increase in altitude, with the pattern first increasing and then decreased. It may exhibit the universal law of the species distribution in Qinghai-Tibet Plateau. The relationship between above-ground biomass and species diversity in the two mountain transects also appeared uniform: above-ground biomass linearly decreased with increased in Shannon-Wiener index, Simpson index and Pielou index, but it was not associated with species richness. Integrating all data from the two mountain transects, we found that the above-ground biomass was not related to Shannon-Wiener and Simpson indices, however it increases linearly with increases in species richness. Based on the research data in the Qinghai-Tibet Plateau, we found the relationship between above-ground biomass and species richness presented an "S" curve (logistic model).

Key words: species diversity, species richness, above-ground biomass, productivity, altitude, diversity index

植物物种多样性海拔梯度的分布格局以及物 种多样性与生产力的关系是生态学研究的热点问 题, 至今还没有得出一般性的规律。研究物种多样 性与生产力的关系对生态系统物种保护和生产力 的维持意义重大。生物多样性沿环境梯度的变化规 律是生物多样性研究的一个重要议题(Kratochwil, 1999), 而物种多样性是描述群落和区域多样性的 最简单有效的方法, 是生物多样性的本质内容 (Magurran, 1988)。海拔梯度由于包含了温度、湿度 和太阳辐射等环境因子, 成为研究物种多样性分布 规律的重要方面(Gaston, 2000)。国内外的生态学者 以不同区域的山体为对象进行了大量研究(唐志尧 和柯金虎, 2004; Dorji et al., 2014)。贺金生和陈伟烈 (1997) 将陆地植物群落物种多样性的海拔梯度变化 特征分为5 种模式: 负相关、“中间高度膨胀”、中等 海拔高度较低、正相关和无关。在目前的研究中, 物 种多样性沿海拔梯度的分布格局较为普遍的是“中 间高度膨胀” (田怀珍和邢福武, 2008; 段敏杰等, 2011; 孔祥海和李振基, 2012; 牛常青等, 2014)和负 相关关系(岳明等, 2002; 卢训令等, 2010)。对于物 种多样性沿海拔梯度的分布规律以及相关机制至 今还没有得出一致结论。

方精云等(2004)实施的“中国山地植物物种多 样性调查计划” (PKU-PSD计划), 对全国主要山地 开展了生物多样性调查。在森林生态系统中针对乔 木、灌木和草本层的研究发现, 由于森林生态系统 层次结构复杂, 相互干扰作用大, 各个层片的变化 规律并不一致(朱源等, 2008; 高远等, 2009; 何艳华 等, 2013; 陈云等, 2014)。然而这些报道主要集中在
森林生态系统, 对草地生态系统物种多样性随海拔 梯度的分布格局及物种多样性与地上生物量关系 的报道仍然较少。

草地生态系统是陆地生态系统的重要组成部 分(赵同谦等, 2004), 维持草地生态系统的稳定和生 产力具有重要的生态、生产和生活意义, 而草地生 态系统稳定性和生产力的维持依赖于草地植物群 落的生物多样性(Tilman et al., 1996)。草地生态系统 的群落结构相对单一, 干扰因素相对较少, 为物种 多样性随海拔梯度的变化及物种多样性与地上生 物量(生产力)的关系研究提供了理想对象。青藏高 原被称为地球的“第三极”, 具有独特的自然地理条 件, 对气候变化较为敏感(Feng et al., 1998; Klein et al., 2004), 其气候变化的相关规律可能表现得更明 显。目前针对青藏高原高寒草甸植物群落开展的研 究较少, 得出的结论也不尽一致(王长庭等, 2004; 周芸芸等, 2011; Dorji et al., 2014)。我们选取位于青 海省海南藏族自治州贵德县的拉脊山 $\left(36^{\circ} 21^{\prime} \mathrm{N}\right.$, $101^{\circ} 27^{\prime} \mathrm{E}$, 海拔3,389-3,876 m) 和果洛藏族自治州 的玛沁县军牧场山体 $\left(34^{\circ} 22^{\prime} \mathrm{N}, 100^{\circ} 30^{\prime} \mathrm{E}\right.$, 海拔 4,121-4,268 m)两条具有代表性的山体样带, 分析 其植物群落特征的规律, 以探讨青藏高原高寒草甸 植物物种多样性随环境因子的变化规律, 为青藏高 原地区草地生态系统的物种保护、较高生产力的维 持以及生态恢复提供科学支撑。

\section{1 方法}

\section{1 研究区概况}

研究区域一位于青海省海南藏族自治州贵德 
县 $\left(35^{\circ} 29^{\prime}-36^{\circ} 23^{\prime} \mathrm{N}, 100^{\circ} 58^{\prime}-101^{\circ} 47^{\prime} \mathrm{E}\right)$ 。该区域属高 原大陆性气候, 年平均降水量约 $254.2 \mathrm{~mm}$, 主要集 中在6-9月。年平均气温 $2.2-7.2^{\circ} \mathrm{C}$, 气温昼夜变化 大, 年均日较差 $14.9^{\circ} \mathrm{C}$ 。该区域光照资源丰富, 平均 年日照时数为 $2,445-2,904 \mathrm{~h}$ 。拉脊山山峰海拔多在 4,000-4,500 m之间, 山上植物资源丰富, 主要优势 种有矮生嵩草 (Kobresia humilis)、大花嵩草 $(K$. macrantha)、垂穗披碱草(Elymus nutans)、金露梅 (Potentilla fruticosa)和紫花针茅(Stipa purpurea)等。 土壤类型以高山草甸土为主。

研究区域二位于青海省果洛藏族自治州玛沈

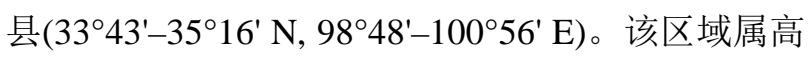
原大陆性气候, 年平均降水量约 $542.1 \mathrm{~mm}$, 主要集 中在6-9月。年平均气温-3.8至 $3.5^{\circ} \mathrm{C}$, 气温低, 昼夜 温差大。全年日照时数2,313-2,607 h, 太阳辐射强。 研究对象平均海拔均在 $4,000 \mathrm{~m}$ 以上, 主要优势种 有紫花针茅、珠芽蓼(Polygonum viviparum)、羊茅 (Festuca ovina)和火线草(Leontopodium leontopodioides)等。土壤类型以高山草甸土为主。

\section{2 样地设置}

于2014年8-9月植被生物量的高峰期, 根据上 述两座山体的高度, 沿山脚到山顶的垂直剖面每隔 一定距离设置 1 个梯度。在拉脊山上共设置 4 个梯度, 海拔分别为: 3,389 $\mathrm{m} 、 3,642 \mathrm{~m} 、 3,780 \mathrm{~m}$ 和3,876 m; 在玛沁县军牧场的山体上共设置 5 个梯度, 海拔分 别为: 4,121 $\mathrm{m} 、 4,161 \mathrm{~m} 、 4,174 \mathrm{~m} 、 4,195 \mathrm{~m}$ 和 $4,268 \mathrm{~m}$ 。 在每一梯度中设置 1 个约 $50 \mathrm{~m} \times 50 \mathrm{~m}$ 的样地, 用 GPS记录仪记录样地的经纬度和海拔高度, 在每块 样地中随机选取 5 个 $50 \mathrm{~cm} \times 50 \mathrm{~cm}$ 的样方(表1)。记 录每个样方中出现的物种, 目测植被的总盖度和每 一物种的分盖度, 并对每一物种分别选取长势相同 的成熟植株3-5株测量其高度。齐地面刚割地上生 物量, 在 $65^{\circ} \mathrm{C}$ 烘箱中烘至恒重, 用电子天平 $(\mathrm{Max}=$ $2,000 \mathrm{~g}, \mathrm{~d}=0.01 \mathrm{~g}$ ) 称量其干重。

\section{3 重要值、多样性指数的计算}

(1)物种重要值 $(I V)=($ 相对高度 + 相对盖度 + 相 对频度) $/ 3$

(2)物种丰富度 $(S)=$ 出现在样方中的物种数 (方精云等, 2009)

$\alpha$ 多样性(Magurran, 1988):

(3) Simpson指数: 


$$
P=1-\sum_{\mathrm{i}=1}^{S} P_{\mathrm{i}}^{2}
$$

(4) Shannon-Wiener指数:

$$
H^{\prime}=-\sum_{\mathrm{i}=1}^{S}\left(P_{\mathrm{i}} \times \ln P_{\mathrm{i}}\right)
$$

(5) Pielou均匀度指数:

$$
E=H^{\prime} / \ln S
$$

其中, $P_{\mathrm{i}}$ 为物种 $\mathrm{i}$ 的重要值 $(I V), S$ 为物种丰富度。

\section{4 数据处理}

利用SPSS 16.0进行回归分析: (1)地上生物量、 物种丰富度、Shannon-Wiener指数、Simpson指数、 Pielou指数与海拔梯度的关系; (2)地上生物量与物 种丰富度、Shannon-Wiener指数、Simpson指数、 Pielou指数的关系, 利用曲线估计 (curve estimation) 进行拟合, 找出有意义且拟合度最优的曲线和方程 (决定系数采用校正后 $R^{2}$ 值, $R^{2}$ 最大, 且 $P<0.05$ ), 利用Kaleida Graph 4.0作图。

\section{2 结果}

\section{1 不同海拔梯度高寒草甸植物群落地上生物量} 的变化

贵德县拉脊山和玛沈县军牧场山体不同海拔 高度高寒草甸植物群落的地上生物量如表1所示。 在两座山体样带上, 地上生物量沿海拔梯度的变化 规律一致, 都随着海拔的升高而线性降低(图1)。

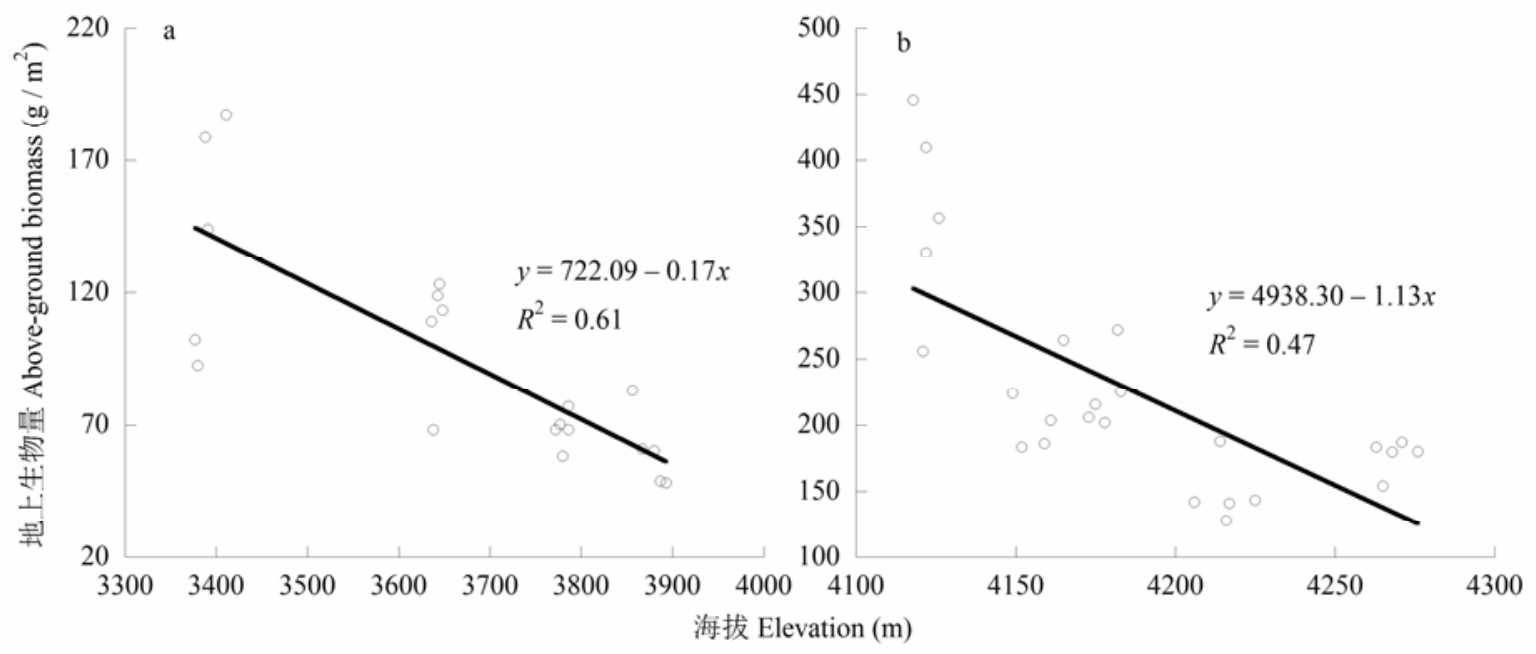

图1 贵德县拉脊山(a)和玛沁县军牧场山体(b)地上生物量随海拔梯度的变化

Fig. 1 Changes of above-ground biomass along an elevation gradient in Laji Mountain, Guide County (a) and Junmuchang Mountain, Maqin County (b)

\section{2 不同海拔梯度高寒草甸植物群落物种多样性 的变化}

由表1可以看出，两条样带不同海拔梯度高寒 草甸植物群落的Shannon-Wiener指数、Simpson指 数、物种丰富度的最大值均出现于中间海拔梯度, 而Pielou均匀度指数的最大值出现在最大海拔梯度 上。并且各项多样性指数与海拔梯度的关系在两条 山体样带上表现一致: Shannon-Wiener指数(图2a、 e)和物种丰富度(图2c、g)均呈峰值明显的单峰曲线, 而Simpson指数(图2b、f)呈峰值不明显的单峰曲线, 这说明在同一座山体上中间海拔梯度有较高的物 种多样性。Pielou指数(图2d、h)随海拔的升高而线 性增加, 说明同一山体植物群落在高海拔处有较高 的均匀度。

\section{3 地上生物量与植物群落物种多样性的关系}

对两条山体样带高寒草甸的地上生物量与物 种多样性指数(Shannon-Wiener指数、Simpson指数、 物种丰富度和Pielou均匀度指数)进行回归分析(图 3), 发现在两座山体上表现出一致的规律: 地上生 物量与物种丰富度没有相关关系(拉脊山: $r=-0.14$, $P=0.56$; 军牧场山体: $r=0.02, P=0.92)$; 但与 Shannon-Wiener指数、Simpson指数和Pielou均匀度 指数呈负相关关系，都随其增加而线性递减。

综合两条山体样带高寒草甸植物群落所有样 方的数据, 发现地上生物量与Shannon-Wiener指数 (图4a)、Simpson指数(图4b)不存在相关关系 $(r=$ 

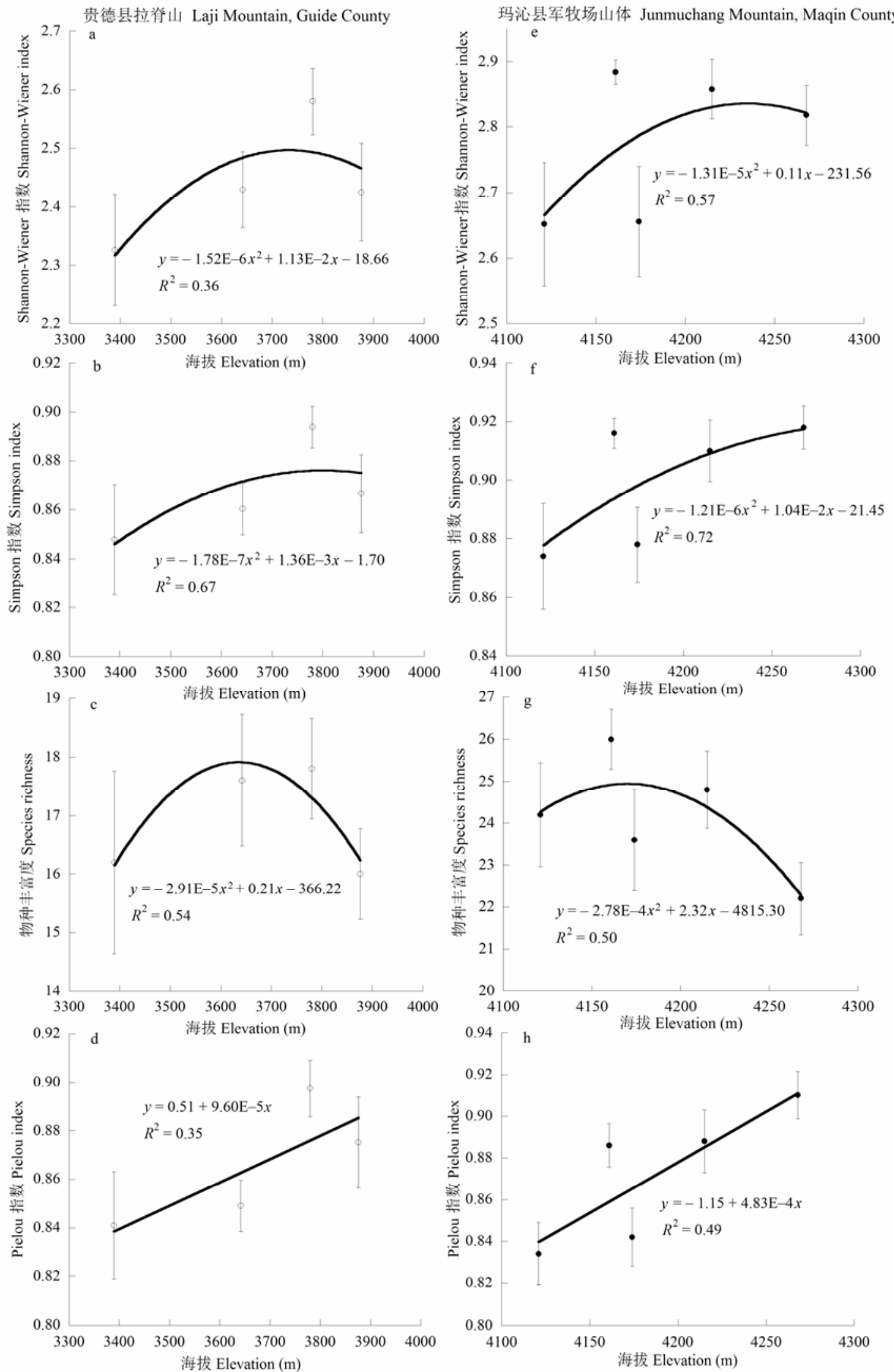

图2 贵德县拉脊山(a至d)和玛沁县军牧场山体(e至h)物种多样性随海拔梯度的变化(平均值土标准误)

Fig. 2 Changes of species diversity along an altitudinal gradient in Laji Mountain, Guide County (a to d) and Junmuchang Mountain, Maqin County (e to h) (mean \pm SE) 


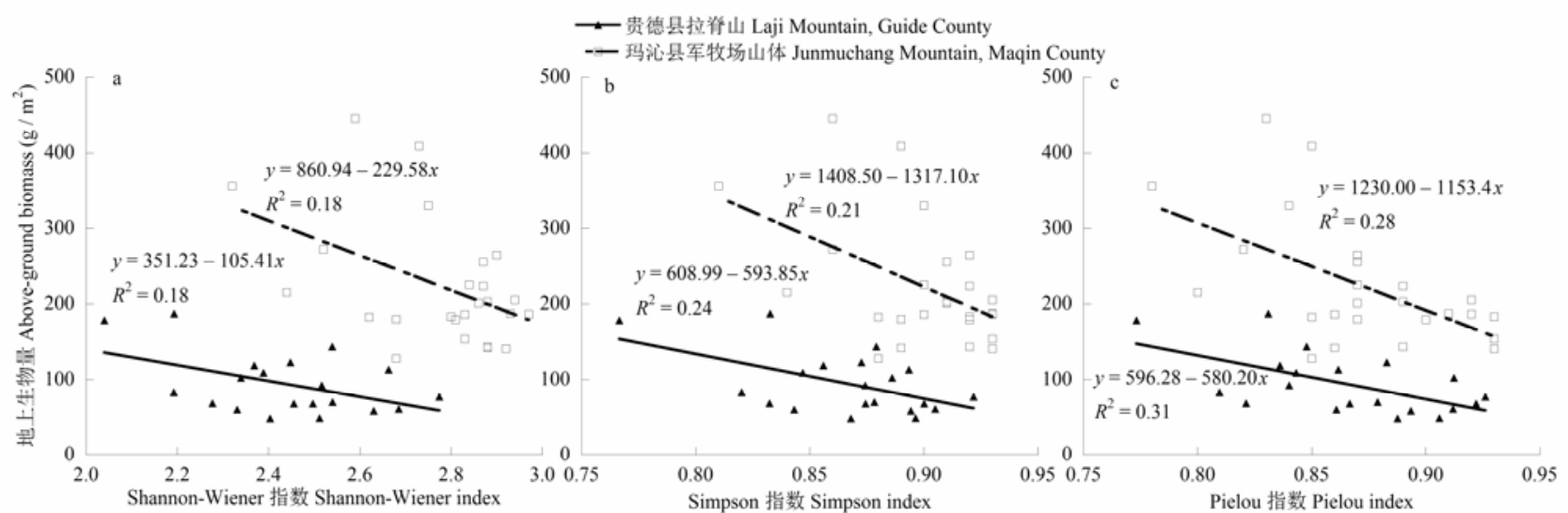

图3 贵德县拉脊山和玛沁县军牧场山体地上生物量与物种多样性的关系

Fig. 3 Relationships of above-ground biomass with species diversity in Laji Mountain, Guide County and Junmuchang Mountain, Maqin County
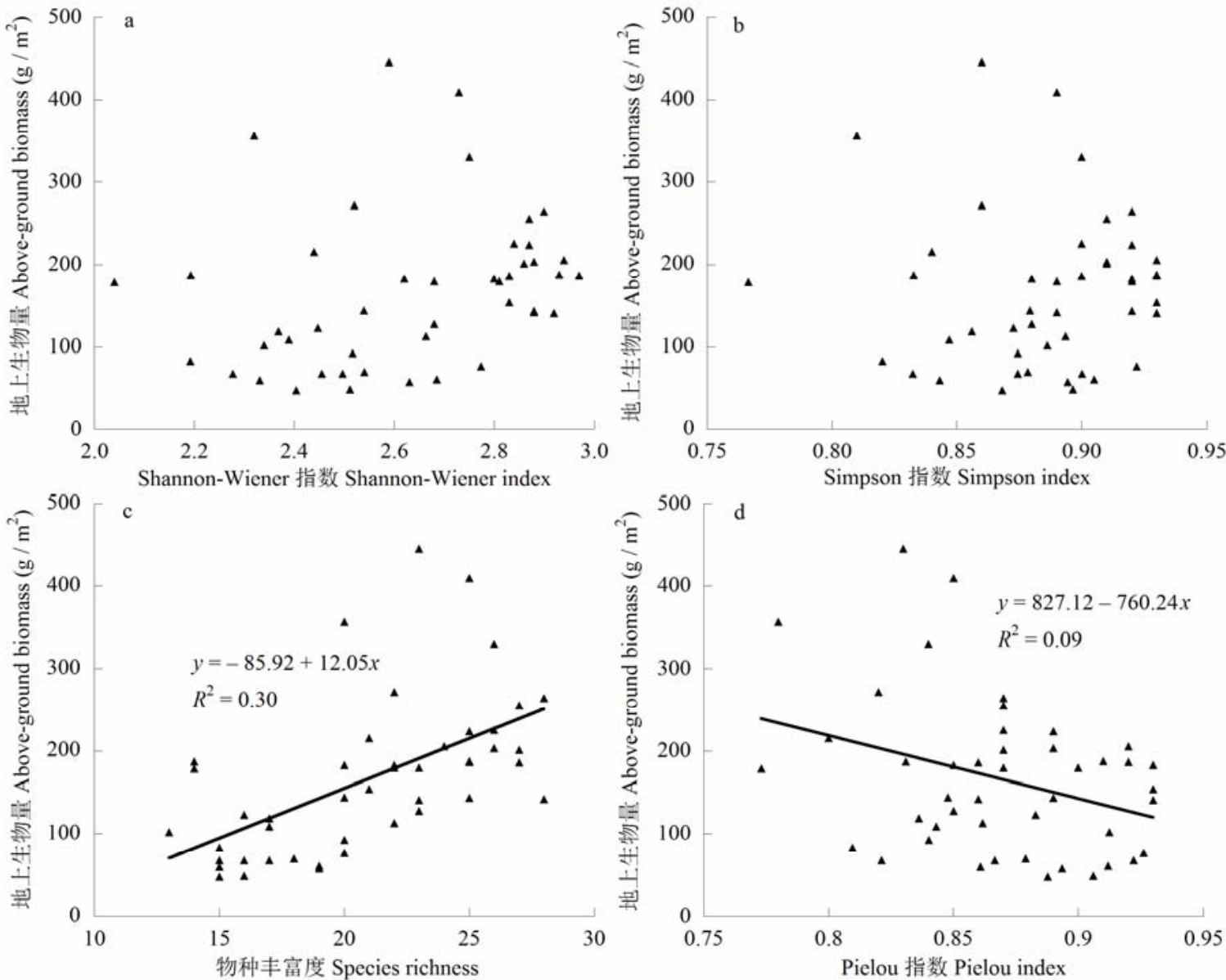

图4 综合贵德县拉脊山和玛沁县军牧场山体样带数据的地上生物量与物种多样性的关系 $(n=45)$

Fig. 4 Relationships of above-ground biomass with species diversity through integrating all data from the Laji Mountain, Guide County and Junmuchang Mountain, Maqin Count $(n=45)$

0.268, $P=0.075 ; r=0.012, P=0.936)$, 而随物种丰 富度(图4c)的升高线性增加; 地上生物量与 Pielou 指数(图4d)呈线性负相关关系，说明群落结构均匀 度大时, 地上生物量(生产力)较小。 


\section{3 讨论}

\section{1 青藏高原物种多样性沿海拔梯度的分布格局}

近几十年来, 国内外生态学家针对物种多样性 沿海拔梯度的分布格局在不同区域进行了大量研 究。刘洋等(2009)综述国内外对山地生态系统的众 多研究发现, 大约75\%的研究显示生物多样性从低 海拔到高海拔呈单峰或偏峰分布格局, 在中海拔处 生物多样性达到最大值; 只有15\%的研究显示多样 性随海拔升高而减少, 少量研究发现多样性随海拔 升高而增加或呈现特殊分布格局。在青藏高原开展 的相关研究中, 物种多样性沿海拔梯度的分布格局 为单峰分布的报道较为普遍(王长庭等, 2004; 段敏 杰等, 2011; Sa et al., 2012), 正相关关系(Shimono et al., 2010; Dorji et al., 2014)和负相关关系(Wang et al., 2006; 周芸芸等, 2011)较少。在本研究中, 物种 多样性(Shannon-Wiener指数、Simpson指数和物种 丰富度)与海拔梯度间的关系呈单峰曲线, 支持单 峰分布格局。

对于多样性指数显示单峰曲线的原因, 有些研 究者将干扰视为重要原因, 认为低海拔梯度受人为 干扰较为严重, 所以其物种多样性较低(唐志尧和 方精云, 2004; 郑成洋等, 2004; 冯建孟等, 2006; da Silva et al., 2014)。但是, 大多数研究认为水热因素、 气候条件等环境因子以及不同生活型物种对环境 的响应不同是造成生物多样性呈单峰曲线的原因 (Whittaker \& Niering, 1965; Ohsawa, 1995; Dorji et al., 2014)。例如, 王长庭等(2004)认为水热条件变化 引起的物种选择、资源竞争以及生境的变化是影响 物种多样性和生产力关系的重要因素; 王国宏 (2002)认为决定群落多样性动态的根本因素是特定 海拔处各环境因子的综合作用所形成的综合资源 量。我们认为是由过度干扰、水热环境与物种竞争 能力三重因素共同作用形成的: 在低海拔梯度, 环 境条件相对优越, 一些竞争能力强的物种会在群落 中占据优势, 人类活动的过度干扰也会导致某些物 种丧失, 所以物种丰富度低; 在高海拔梯度, 水热 条件比低海拔梯度恶劣(陈学林, 2010), 某些物种可 能会因为不适应水热环境而不再出现, 物种丰富度 也较低; 而在中间海拔梯度, 人为干扰因素比低海 拔地区小, 水热因素比高海拔梯度优越, 所以物种 丰富度高。低海拔梯度的过度人为干扰、高海拔梯
度较为不适的水热环境, 再加上物种竞争能力的差 异，3者共同作用形成了“两头低，中间高”的单峰分 布格局。

除这些因素外, 很多学者认为研究尺度、海拔 梯度范围的大小是造成物种多样性沿海拔梯度分 布格局不同的重要原因(唐志尧和方精云, 2004; 刘 兴良等, 2005; Nogues-Bravo et al., 2008)。结合目前 针对青藏高原高寒草甸植物群落的报道数据(孙海 群等, 2000; 贺连选和刘宝汉, 2005; 安尼瓦尔·买买 提等, 2006; Wang et al., 2007; 胡玉昆等, 2007; 段 敏杰等, 2011; 周芸芸等, 2011; Sa et al., 2012; 索南 措 $\left.^{(}\right)$, 对海拔 2,000-5,000 m范围内物种丰富度与海 拔的关系进行回归分析 $\left(y=-1.23 \mathrm{E}-5 x^{2}+8.54 \mathrm{E}-2 x\right.$ $-118.07, R^{2}=0.19, P<0.001$ ) (图5), 发现物种丰富 度随海拔的升高表现为单峰曲线，在中间海拔梯度 (3,500 m左右) 出现最大值, 说明随海拔的升高物种 多样性先升高后降低可能是青藏高原物种多样性 分布的普遍规律。这种分布规律可能与 $3,100 \mathrm{~m}$ 左右 的中高海拔是许多青藏高原植物区系原始类群集 中分布的地段有关(陈学林, 2010)。

\section{2 青藏高原物种多样性与地上生物量(生产力)的 关系}

植物群落物种多样性与生产力的关系一直是 生态学研究的热点(Wilson \& Keddy, 1988; Gough et al., 1994; Mittelbach et al., 2001; Alhamad et al., 2010)。大量研究表明, 物种多样性与生产力的关系 有多种形式: $30 \%$ 呈单峰关系，26\%呈正线性关系， 12\%呈负线性关系，32\%关系不明显(Waide et al., 1999)。单峰曲线关系(hump-shaped)是研究较早的一 种关系(Rosenzweig \& Abramsky, 1993)。现在有学者 认为物种多样性与生产力无论在小尺度上还是在 全球尺度上都没有相关关系(Adler et al., 2011)，但 这一观点也遭到其他学者的反驳, 认为其研究在区 域分析上没有充足数据并且缺乏高生产力样点的 数据, 得出的结论不可信(Fridley et al., 2012; Pan et al., 2012)。

在青藏高原的相关研究中, 物种多样性与地上 生物量(生产力)的关系有单峰曲线关系(Kassen et $a l ., 2000$; 王长庭等, 2004; 安尼瓦尔·买买提等, 2006; 朱源等, 2008)、负相关关系(李凯辉等, 2007)

(1) 索南措 (2013) 青藏高原东缘高寒草甸植被特征与土壤性质随海拔 变化的响应研究。西北师范大学硕士学位论文, 兰州。 


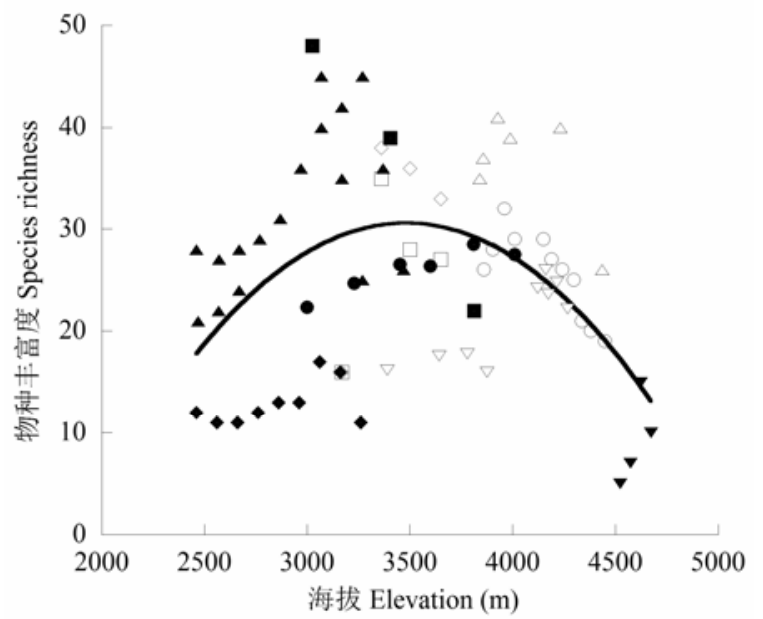

图5 青藏高原物种丰富度沿海拔梯度的分布格局。数据分 别来源于下列文献: $\diamond$ 孙海群等, 2000; $\square$ 贺连选和刘宝 汉, 2005; $\Delta$ 安尼瓦尔.买买提等, 2006; $\triangle$ Wang et al., 2007; 胡玉昆等, 2007; $\nabla$ 段敏杰等, 2011; - 周芸芸等, 2011; ○ Sa et al., 2012); ・索南措 ${ }^{\circledR}$; $\nabla$ 本研究。

Fig. 5 Distribution of species richness with elevation gradient in Qinghai-Tibet Plateau. The data are derived from the following papers: $\diamond$ Sun et al., 2000; $\square$ He et al., 2005; $\boldsymbol{\Delta}$ Anwar Mohammat et al., 2006; $\triangle$ Wang et al., 2007; $>\mathrm{Hu}$ et al., 2007; $\boldsymbol{\nabla}$ Duan et al., 2011; - Zhou et al., 2011; O Sa et al., 2012; • Suo ${ }^{(1)} \nabla$ present study.

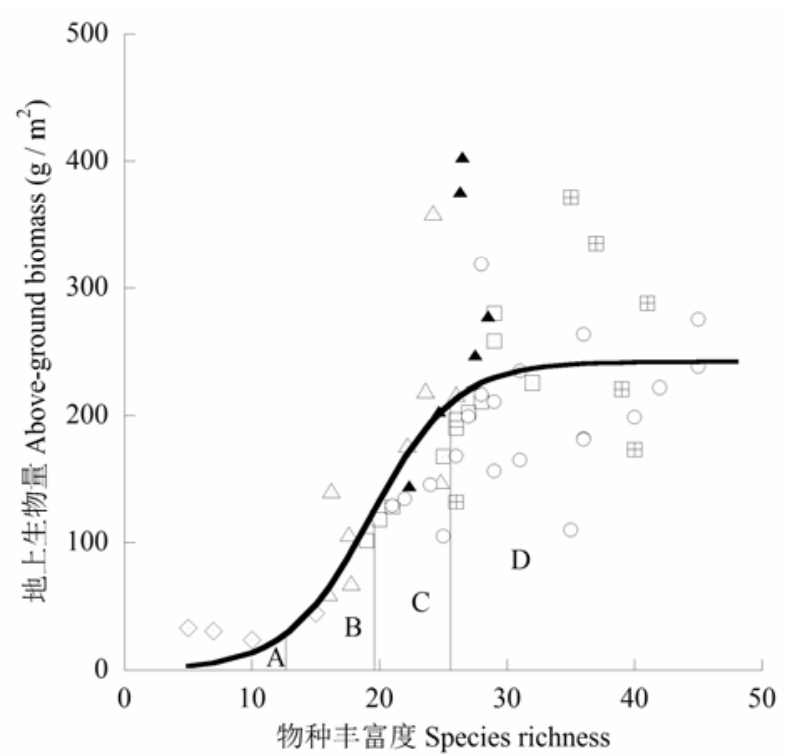

图6 青藏高原自然放牧生态系统地上生物量与物种丰富度 的关系。数据分别来源于下列文献: $\triangle$ 安尼瓦尔. 买买提等,

2006; $\diamond$ Wang et al., 2007; $\square$ 段敏杰等, 2011; $\bigcirc$ Sa et al., 2012; 田 索南措 ${ }^{\circledR}$; 本研究。

Fig. 6 Relationship of above-ground biomass with species richness in the natural grazing ecosystem in Qinghai-Tibet Plateau. The data are derived from the following papers: $\triangle$ Anwar Mohammat et al., 2006; $\diamond$ Wang et al., 2007; $\square$ Duan et al., 2011; O Sa et al., 2012; 田 Suo ${ }^{\mathbb{1}}$; $\Delta$ present study.
和正相关关系(覃光莲等, 2002; 杜国祯等, 2003; 刘 旻霞等, 2013)。本研究中, 物种多样性与地上生物 量在小尺度(单一山体样带)呈负相关关系(图3), 但 是综合两座山体样带所有样方数据后变成了正相 关关系(图4c), 这一研究结果与Kessler等(2014)在 对陆生蕨类植物的研究中得到的物种丰富度与硕 类地上生物量在小尺度上负相关、在大尺度上正相 关的结果类似。同时杨元合等(2004)在青藏高原高 寒草原与高寒草甸植物群落进行了大范围的调查 后也得到物种丰富度与地上生物量显著正相关的 结论，说明尺度问题对物种多样性与地上生物量 (生产力)的关系研究也非常重要。对于在大尺度上 物种丰富度与生产力呈正相关关系的原因, Harrison和Grace (2007) 提出了 “生物地理亲和力假说” (Biogeographic Affinity Hypothesis), 认为这是物种 对气候的耐受功能, 这种功能是由地球的气候历史 和物种生态位的进化保守性共同造就的。

结合目前针对青藏高原高寒草甸植物群落的 相关研究数据(安尼瓦尔. 买买提等, 2006; Wang et al., 2007; 段敏杰等, 2011; Sa et al., 2012; 索南措 ${ }^{(1)}$ ), 发现在自然放牧高寒草甸生态系统中物种丰富度 与地上生物量呈 $\mathrm{S}$ 型曲线关系, 表现为logistic model (图6): 当物种丰富度低于12种时, 地上生物量随 物种丰富度的升高增长缓慢; 当物种丰富度在 12-19种之间时，地上生物量随物种丰富度的升高 快速增加; 当物种丰富度大于 26 种时, 群落的地上 生物量(生产力)逐渐趋于稳定。这一结果更好地解 释了前人关于青藏高原高寒草甸植物群落物种多 样性与地上生物量(生产力)之间关系不一致(杜国 祜等, 2003; 李凯辉等, 2007; 朱源等, 2008)的原因。 当物种丰富度大于某一值时, 群落地上生物量(生 产力)趋于稳定(Zhou et al., 2006), 其研究区域的物 种丰富度恰好处于 $\mathrm{D}$ 段(图6), 净初级生产力虽然有 年际波动但处于稳定状态。本文中两条山体样带物 种丰富度刚好处于20-30 (C段) (图6)。因此, 研究区 域物种丰富度处于不同的阶段时, 其与地上生物量 之间的关系不同。

物种丰富度与地上生物量 $\mathrm{S}$ 型曲线关系是基于 70多个样点的数据得到的, 并未包含青藏高原所有 的草地生态系统类型, 今后需要增大样本量和生态

(1) 索南措 (2013) 青藏高原东缘高寒草甸植被特征与土壤性质随海拔 变化的响应研究。西北师范大学硕士学位论文, 兰州。 
系统类型来验证这一规律的普适性。

\section{3 对青藏高原高寒草地生态系统管理的建议}

放牧是青藏高原高寒草地生态系统最主要的 干扰因素。在青藏高原的放牧生态系统中, 放牧强 度和频率直接影响草地植物群落结构和植物多样 性, 进而影响家畜生产力、草地恢复力和稳定性(付 伟等, 2013)。目前的很多研究表明, 随着放牧强度 的增加, 物种丰富度表现为单峰变化(即适度放牧 最大) (江小蕾等, 2003; 王长庭等, 2008; 仁青吉等, 2009; 郑伟等, 2012), 当放牧强度处于中等水平(轻 度或中度)时, 物种丰富度处于 D段(图6), 此时地上 生物量(生产力)最大, 生态系统处于稳定状态; 但 当放牧强度处于重度或过度水平时, 物种丰富度处 于 $\mathrm{A} 、 \mathrm{~B}$ 段, 生态系统大部分物种丧失, 地上生物量 降低, 开始出现退化趋势。因此, 依据物种丰富度 与地上生物量的关系(图6), 为了保护高寒草地, 物 种丰富度应该保持在 $\mathrm{D}$ 段。已有研究表明, 适度放 牧可维持物种丰富度(Zou等, 2014; 赵亮等, 2014), 这也即目前很多研究提倡适度(轻度或中度)放牧 (徐广平等, 2005; 李文龙等, 2008; 益西措姆等, 2014)的原因所在。

\section{参考文献}

Adler PB, Seabloom EW, Borer ET, Hillebrand H, Hautier Y, Hector A, Harpole WS, O’Halloran LR, Grace JB, Anderson TM, Bakker JD, Biederman LA, Brown CS, Buckley YM, Calabrese LB, Chu CJ, Cleland EE, Collins SL, Cottingham KL, Crawley MJ, Damschen EI, Davies KF, DeCrappeo NM, Fay PA, Firn J, Frater P, Gasarch EI, Gruner DS, Hagenah N, Lambers JHR, Humphries H, Jin VL, Kay AD, Kirkman KP, Klein JA, Knops JMH, La Pierre KJ, Lambrinos JG, Li W, MacDougall AS, McCulley RL, Melbourne BA, Mitchell CE, Moore JL, Morgan JW, Mortensen B, Orrock JL, Prober SM, Pyke DA, Risch AC, Schuetz M, Smith MD, Stevens CJ, Sullivan LL, Wang G, Wragg PD, Wright JP, Yang LH (2011) Productivity is a poor predictor of plant species richness. Science, 333, 1750-1753.

Alhamad MN, Oswald BP, Bataineh MM, Alrababah MA, Al-Gharaibeh MM (2010) Relationships between herbaceous diversity and biomass in two habitats in arid Mediterranean rangeland. Journal of Arid Environments, 74, 277-283.

Anwar Mohammat (安尼瓦尔・买买提), Yang YH (杨元合), Guo ZD (郭兆迪), Fang JY (方精云), Pan BR (潘伯荣), Hu YK (胡玉昆) (2006) Relationship between the species richness and the productivity of alpine steppes in Bayanbulak, Xinjiang. Arid Zone Research (干旱区研究), 23, 289-294. (in Chinese with English abstract)
Chen XL (陈学林) (2010) Studies on Evolutionary Ecology of Seed Size Variation in the Eastern Qinghai-Tibet Plateau Flora, and the Vertival Distribution Implications of Adaptive Radiation of Seed Size (青藏高原东缘种子大小变异的 进化生态学研究——兼论种子大小适应辐射的空间格局 证据). PhD dissertation, Lanzhou University, Lanzhou. (in Chinese with English abstract)

Chen Y (陈云), Wang HL (王海亮), Han JW (韩军旺), Wei BL (韦博良), Jia HR (贾宏汝), Ye YZ (叶永忠), Yuan ZL (袁志良) (2014) Numerical classification, ordination and species diversity along elevation gradients of the forest community in Xiaoqinling. Acta Ecologica Sinica (生态学 报), 34, 2068-2075. (in Chinese with English abstract)

da Silva FKG, Lopes SD, Lopez LCS, de Melo JIM, Trovao D (2014) Patterns of species richness and conservation in the Caatinga along elevational gradients in a semiarid ecosystem. Journal of Arid Environments, 110, 47-52.

Dorji T, Moe SR, Klein JA, Totland O (2014) Plant species richness, evenness, and composition along environmental gradients in an alpine meadow grazing ecosystem in central Tibet, China. Arctic Antarctic and Alpine Research, 46, 308-326.

Du GZ (杜国祯), Qin GL (覃光莲), Li ZZ (李自珍), Liu ZH (刘正恒), Dong GS (董高生) (2003) Relationship between productivity and species diversity in alpine meadow plant community. Acta Phytoecologica Sinica (植物生态学报), 27, 125-132. (in Chinese with English abstract)

Duan MJ (段敏杰), Gao QZ (高清竹), Guo YQ (郭亚奇), Wan YF (万运帆), Li YE (李玉娥), Ganzhuzhabu (干珠扎布), Danjiuluobu (旦久罗布), Wei LT (韦兰亭), Xiraozhuoma (西饶卓玛) (2011) Species diversity distribution pattern of alpine grassland communities along an altitudinal gradient in the northern Tibet. Pratacultural Science (草业科学), 28, 1845-1850. (in Chinese with English abstract)

Fang JY (方精云), Shen ZH (沈泽吴), Tang ZY (唐志尧), Wang ZH (王志恒) (2004) The protocol for the survey plan for plant species diversity of China's mountains. Biodiversity Science (生物多样性), 12, 5-9. (in Chinese with English abstract)

Fang JY (方精云), Wang XP (王襄平), Shen ZH (沈泽吴), Tang ZY (唐志尧), He JS (贺金生), Yu D (于丹), Jiang Y (江源), Wang ZH (王志恒), Zheng CY (郑成洋), Zhu JL (朱江玲), Guo ZD (郭兆迪) (2009) Methods and protocols for plant community inventory. Biodiversity Science (生物 多样性), 17, 533-548. (in Chinese with English abstract)

Feng JM (冯建孟), Wang XP (王襄平), Xu CD (徐成东), Yang YH (杨元合), Fang JY (方精云) (2006) Altitudinal patterns of plant species diversity and community structure on Yulong Mountains, Yunnan, China. Journal of Mountain Science (山地学报), 24, 110-116. (in Chinese with English abstract)

Feng S, Tang MC, Wang DM (1998) New evidence for the Qinghai-Xizang (Tibet) Plateau as a pilot region of climatic 
fluctuation in China. Chinese Science Bulletin, 43, 1745-1749.

Fridley JD, Grime JP, Huston MA, Pierce S, Smart SM, Thompson K, Borger L, Brooker RW, Cerabolini BEL, Gross N, Liancourt P, Michalet R, Le Bagousse-Pinguet Y (2012) Comment on "Productivity Is a Poor Predictor of Plant Species Richness”. Science, 335, 1441.

Fu W (付伟), Zhao JQ (赵俊权), Du GZ (杜国祯) (2013) Study on sustainable development of alpine grazing ecosystem on Qinghai-Tibetan Plateau. Grassland and Turf (草原 与草坪), 33(1), 84-88. (in Chinese with English abstract)

Gao Y (高远), Ci HX (慈海金金), Qiu ZL (邱振鲁), Chen YF (陈玉峰) (2009) Plant diversity and its elevational gradient patterns in Mengshan Mountain, Shandong, China. Acta Ecologica Sinica (生态学报), 29, 6377-6384. (in Chinese with English abstract)

Gaston KJ (2000) Global patterns in biodiversity. Nature, 405, 220-227.

Gough L, Grace JB, Taylor KL (1994) The relationship between species richness and community biomass: the importance of environmental variables. Oikos, 70, 271-279.

Harrison S, Grace JB (2007) Biogeographic affinity helps explain productivity-richness relationships at regional and local scales. The American Naturalist, 170, S5-S15.

He JS (贺金生), Chen WL (陈伟烈) (1997) A review of gradient changes in species diversity of land plant communities. Acta Ecologica Sinica (生态学报), 17, 93-101. (in Chinese with English abstract)

He LX (贺连选), Liu BH (刘宝汉) (2005) Study on diversity of plant community in alpine-cold meadow at different altitude. Chinese Qinghai Journal of Animal and Veterinary Sciences (青海畜牧兽医杂志), 35(5), 1-4. (in Chinese with English abstract)

He YH (何艳华), Yan M (阊明), Zhang QD (张钦弟), Zhang ZF (张直峰), Miao YM (苗艳明), Bi RC (毕润成) (2013) Altitudinal pattern of plant species diversity in the Wulu Mountain Nature Reserve, Shanxi, China. Acta Ecologica Sinica (生态学报), 33, 2452-2462. (in Chinese with English abstract)

Hu YK (胡玉昆), Li KH (李凯辉), Adeli Maidy (阿德力•麦 地), Liu YY (柳妍妍), Fan YG (范永刚), Wang X (王金), Gao GG (高国刚) (2007) Plant species diversity of alpine grasslands on southern slope of Tianshan Mountain along altitude gradient. Chinese Journal of Ecology (生态学杂志), 26, 182-186. (in Chinese with English abstract)

Jiang XL (江小蕾), Zhang WG (张卫国), Yang ZY (杨振宇), Wang G (王刚) (2003) The influence of disturbance on community structure and plant diversity of alpine meadow. Acta Botanica Boreali-Occidentalia Sinica (西北植物学报), 23, 1479-1485. (in Chinese with English abstract)

Kassen R, Buckling A, Bell G, Rainey PB (2000) Diversity peaks at intermediate productivity in a laboratory microcosm. Nature, 406, 508-512.

Kessler M, Salazar L, Homeier J, Kluge J (2014) Species rich- ness-productivity relationships of tropical terrestrial ferns at regional and local scales. Journal of Ecology, 102, 1623-1633.

Klein JA, Harte J, Zhao XQ (2004) Experimental warming causes large and rapid species loss, dampened by simulated grazing, on the Tibetan Plateau. Ecology Letters, 7, 1170-1179.

Kong XH (孔祥海), Li ZJ (李振基) (2012) Species diversity and altitudinal gradient patterns of evergreen broad-leaved forest in Meihuashan National Nature Reserve, Fujian Province. Plant Diversity and Resources (植物分类与资源学 报), 34, 179-186. (in Chinese with English abstract)

Kratochwil A (1999) Biodiversity in Ecosystems: Principles and Case Studies of Different Complexity Levels. Springer, Netherlands.

Li KH (李凯辉), Hu YK (胡玉昆), Adeli Maidy (阿德力・麦 地), Yu JM (于建梅), Gao GG (高国刚) (2007) Species diversity and above-ground biomass of alpine grassland on the southern slope of Tianshan Mountain. Journal of Arid Land Resources and Environment (干旱区资源与环境), 21, 155-159. (in Chinese with English abstract)

Li WL (李文龙), Su M (苏敏), Li ZZ (李自珍) (2008) Optimal control pattern for grazing management in alpine meadows. Journal of Lanzhou University (Natural Sciences) (兰州大 学学报(自然科学版)), 44(5), 30-34, 39. (in Chinese with English abstract)

Liu MX (刘旻霞), Wang G (王刚), Sheng HM (盛红梅) (2013) Environmental factors characteristic of sunny and shady slope gradients in relation to above-ground biomass and species richness in an alpine meadow. Journal of Lanzhou University (Natural Sciences) (兰州大学学报(自然科 学版)), 49(1), 76-81. (in Chinese with English abstract)

Liu XL (刘兴良), Shi ZM (史作民), Yang DS (杨冬生), Liu SR (刘世荣), Yang YP (杨玉坡), Ma QY (马钦彦) (2005) Advances in study on changes of biodiversity and productivity along elevational gradient in mountainous plant community. World Forestry Research (世界林业研究), 18(4), 27-34. (in Chinese with English abstract)

Liu Y (刘洋), Zhang J (张健), Yang WQ (杨万勤) (2009) Responses of alpine biodiversity to climate change. Biodiversity Science (生物多样性), 17, 88-96. (in Chinese with English abstract)

Lu XL (卢训令), Hu N (胡楠), Ding SY (丁圣彦), Fan YL (范 玉龙), Liao BH (廖秉华), Zhai YJ (翟元杰), Liu J (柳静) (2010) The pattern of plant species diversity of Funiu Mountain Nature Reserve. Acta Ecologica Sinica (生态学 报), 30, 5790-5798. (in Chinese with English abstract)

Magurran AE (1988) Ecological Diversity and Its Measurement. Princeton University Press, Princeton.

Mittelbach GG, Steiner CF, Scheiner SM, Gross KL, Reynolds HL, Waide RB, Willig MR, Dodson SI, Gough L (2001) What is the observed relationship between species richness and productivity? Ecology, 82, 2381-2396.

Niu CQ (牛常青), Qu B (曲波), Niu XX (牛霞霞) (2014) Ver- 
tical distribution pattern of plant community species diversity in Mt. Wujin. Journal of Jinzhong University (晋中学院 学报), 31(3), 56-63. (in Chinese with English abstract)

Nogues-Bravo D, Araujo MB, Romdal T, Rahbek C (2008) Scale effects and human impact on the elevational species richness gradients. Nature, 453, 216-219.

Ohsawa M (1995) Latitudinal comparison of altitudinal changes in forest structure, leaf-type, and species richness in humid monsoon Asia. Vegetatio, 121, 3-10.

Pan XB, Liu FQ, Zhang M (2012) Comment on "Productivity Is a Poor Predictor of Plant Species Richness”. Science, 335, 1441.

Qin GL (覃光莲), Du GZ (杜国祯), Li ZZ (李自珍), Yang GY (杨广运), Ma JY (马建云), Niang MJ (娘毛加) (2002) Relationship between productivity and species diversity in alpine meadow plant community. Acta Phytoecologica Sinica (植物生态学报), 26, 57-62. (in Chinese with English abstract)

Ren QJ (仁青吉), Wu GL (武高林), Ren GH (任国华) (2009) Effect of grazing intensity on characteristics of alpine meadow communities in the eastern Qinghai-Tibetan Plateau. Acta Prataculturae Sinica (草业学报), 18, 256-261. (in Chinese with English abstract)

Rosenzweig ML, Abramsky Z (1993) How are diversity and productivity related. In: Species Diversity in Ecological Communities: Historical and Geographical Perspectives (eds Robert ER, Dolph S), pp. 52-65. University of Chicago Press, Chicago.

Sa W, An L, Sa W (2012) Changes in plant community diversity and aboveground biomass along with altitude within an alpine meadow on the Three-River source region. Chinese Science Bulletin, 57, 3573-3577.

Shimono A, Zhou HK, Shen HH, Hirota M, Ohtsuka T, Tang YH (2010) Patterns of plant diversity at high altitudes on the Qinghai-Tibetan Plateau. Journal of Plant Ecology, 3, 1-7.

Sun HQ (孙海群), Zhu ZH (朱志红), Qiao YM (乔有明), Li XL (李希来), Pei HK (裴海崑), Liu ZK (刘振魁) (2000) Kobresia pygmaea meadow plant community diversity in relation to altitude gradient. Grassland of China (中国草 地), (5), 19-23. (in Chinese with English abstract)

Tang ZY (唐志尧), Fang JY (方精云) (2004) A review on the elevational patterns of plant species diversity. Biodiversity Science (生物多样性), 12, 20-28. (in Chinese with English abstract)

Tang ZY (唐志尧), Ke JH (柯金虎) (2004) Altitudinal patterns of plant species diversity in Mt. Niubeiliang, Qinling Mountains. Biodiversity Science (生物多样性), 12, 108-114. (in Chinese with English abstract)

Tian HZ (田怀珍), Xing FW (邢福武) (2008) Elevational diversity patterns of orchids in Nanling National Nature Reserve, northern Guangdong Province. Biodiversity Science (生物多样性), 16, 75-82. (in Chinese with English abstract)

Tilman D, Wedin D, Knops J (1996) Productivity and sustainability influenced by biodiversity in grassland ecosystems.
Nature, 379, 718-720.

Waide RB, Willig MR, Steiner CF, Mittelbach G, Gough L, Dodson SI, Juday GP, Parmenter R (1999) The relationship between productivity and species richness. Annual Review of Ecology and Systematics, 30, 257-300.

Wang CT (王长庭), Long RJ (龙瑞军), Wang QL (王启兰), Cao GM (曹广民), Shi JJ (施建军), Du YG (杜岩功) (2008) Response of plant diversity and productivity to soil resources changing under grazing disturbance on an alpine meadow. Acta Ecologica Sinica (生态学报), $\mathbf{2 8}$, 4144-4152. (in Chinese with English abstract)

Wang CT (王长庭), Wang QJ (王启基), Long RJ (龙瑞军), Jing ZC (景增春), Shi HL (史惠兰) (2004) Changes in plant species diversity and productivity along an elevation gradient in an alpine meadow. Acta Phytoecologica Sinica (植物 生态学报), 28, 240-245. (in Chinese with English abstract)

Wang CT, Long RJ, Wang QJ, Ding LM, Wang MP (2007) Effects of altitude on plant-species diversity and productivity in an alpine meadow, Qinghai-Tibetan plateau. Australian Journal of Botany, 55, 110-117.

Wang GH (王国宏) (2002) Species diversity of plant communities along an altitudinal gradient in the middle section of northern slopes of Qilian Mountains, Zhangye, Gansu, China. Biodiversity Science (生物多样性), 10, 7-14. (in Chinese with English abstract)

Wang WY, Wang QJ, Li SX, Wang G (2006) Distribution and species diversity of plant communities along transect on the northeastern Tibetan Plateau. Biodiversity and Conservation, 15, 1811-1828.

Whittaker RH, Niering WA (1965) Vegetation of the Santa Catalina Mountains, Arizona: a gradient analysis of the south slope. Ecology, 46, 429-452.

Wilson SD, Keddy PA (1988) Species richness, survivorship, and biomass accumulation along an environmental gradient. Oikos, 53, 375-380.

Xu GP (徐广平), Zhang DG (张德罡), Xu CL (徐长林), Pu XP (蒲小鹏), Liu XJ (刘晓静), Liu XN (柳小妮), Chen JG (陈 建纲) (2005) Effect of grazing disturbance on species diversity of alpine grassland plant community in Eastern Qilian Mountains. Journal of Gansu Agricultural University (甘肃 农业大学学报), 40, 789-796. (in Chinese with English abstract)

Yang YH (杨元合), Rao S (饶胜), Hu HF (胡会峰), Chen AP (陈安平), Ji CJ (吉成均), Zhu B (朱彪), Zuo WY (左闻韵), Li XR (李轩然), Shen HH (沈海花), Wang ZH (王志恒), Tang YH (唐艳鸿), Fang JY (方精云) (2004) Plant species richness of alpine grasslands in relation to environmental factors and biomass on the Tibetan Plateau. Biodiversity Science (生物多样性), 12, 200-205. (in Chinese with English abstract)

Yixicuomu (益西措姆), Xu YF (许岳飞), Fu JJ (付娟娟), Sun YF (孙永芳), Basangjiba (巴桑吉巴), Nibu (尼布), Hu TM (呼天明), Miao YJ (苗彦军) (2014) Effects of grazing intensity on vegetation and soil physicochemical properties of 
alpine meadow in Tibet. Journal of Northwest A\&F University (Natural Science Edition) (西北农林科技大学学报(自 然科学版)), 42(6), 27-33. (in Chinese with English abstract)

Yue M (岳明), Zhang LJ (张林静), Dang GD (党高弟), Gu TQ (辜天琪) (2002) The relationships of higher plant diversity and elevation gradient in Foping National Reserve. Scientia Geographica Sinica (地理科学), 22, 349-354. (in Chinese with English abstract)

Zhao L (赵亮), Li Q (李奇), Chen DD (陈懂懂), Xu SX (徐世 晓), Zhou HK (周华坤), Wang SP (汪诗平), Zhao XQ (赵 新全) (2014) Principles of alpine grassland ecosystems carbon sequestration and management practices on Sanjiangyuan regions, Qinghai-Tibetan Plateau. Quaternary Sciences (第四纪研究), 34, 795-802. (in Chinese with English abstract)

Zhao TQ (赵同谦), Ouyang ZY (欧阳志云), Jia LQ (贾良清), Zheng H (郑华) (2004) Ecosystem services and their valuation of China grassland. Acta Ecologica Sinica (生态学报), 24, 1101-1110. (in Chinese with English abstract)

Zheng CY (郑成洋), Liu ZL (刘增力), Fang JY (方精云) (2004) Tree species diversity along altitudinal gradient on southeastern and northwestern slopes of Mt. Huanggang, Wuyi Mountains, Fujian, China. Biodiversity Science (生物 多样性), 12, 63-74. (in Chinese with English abstract)
Zheng W (郑伟), Dong QM (董全民), Li SX (李世雄), Li HT (李红涛), Liu Y (刘玉), Yang SH (杨时海) (2012) Impact of grazing intensities on community biodiversity and productivity of alpine grassland in Qinghai Lake region. Acta Agrestia Sinica (草地学报), 20, 1033-1038. (in Chinese with English abstract)

Zhou HK, Zhou L, Zhao XQ, Liu W, Li YN, Gu S, Zhou XM (2006) Stability of alpine meadow ecosystem on the Qinghai-Tibetan Plateau. Chinese Science Bulletin, 51, 320-327.

Zhou YY (周芸芸), Zhao MJ (赵敏杰), Li XM (李熙萌), Ma S (马帅), Feng JC (冯金朝) (2011) Study on species diversity of alpine vegetation with different altitudes in Daban Mountain. Journal of Anhui Agricultural Sciences (安徽农 业科学), 39, 8028-8030, 8099. (in Chinese with English abstract)

Zhu Y (朱源), Kang MY (康慕谊), Jiang Y (江源), Liu QR (刘 全儒) (2008) Altitudinal pattern of species diversity in woody plant communities of Mountain Helan, northwestern China. Journal of Plant Ecology (Chinese Version) (植物生 态学报), 32, 574-581. (in Chinese with English abstract)

Zou J, Zhao L, Xu S, Xu X, Chen D, Li Q, Zhao N, Luo C, Zhao X (2014) Field ${ }^{13} \mathrm{CO}_{2}$ pulse labeling reveals differential partitioning patterns of photoassimilated carbon in response to livestock exclosure in a Kobresia meadow. Biogeosciences, 11, 4381-4391.

(责任编委：白永飞 责任编辑：黄祥忠) 